\title{
Peptide Utilization by Group N Streptococci
}

\author{
By B. A. LA W \\ National Institute for Research in Dairying, Shinfield, Reading RG2 9AT
}

(Received 11 August 1977; revised 3 October 1977)

\begin{abstract}
The rate of glycylleucine uptake by Group N streptococci varied widely. One strain of Streptococcus cremoris did not transport the dipeptide or utilize tripeptides. In peptideutilizing strains, amino acid, dipeptide and tripeptide transport were distinct, although dipeptides inhibited tripeptide utilization. Specificity determinants for peptide transport and utilization were similar to those reported in Gram-negative bacteria. Peptide utilization in $S$. lactis was not completely dependent on the transport of intact peptides.
\end{abstract}

\section{INTRODUCTION}

The transport of peptides into bacterial cells has been demonstrated in a wide variety of micro-organisms and the specificities of the transport systems in Escherichia coli have been determined (Payne, 1976). However, relatively little is known about peptide uptake in Group N streptococci, which require exogenous supplies of some of the amino acids for growth (Law, Sezgin \& Sharpe, 1976). In order to perform their industrial function as starter cultures in fermented milk products, these streptococci must grow in milk, which contains relatively low concentrations of free amino acids (Lawrence, Thomas \& Terzaghi, 1976). Thomas, Jarvis \& Skipper (1974) and Exterkate (1975) demonstrated the presence in Group N streptococci of cell wall-bound proteinases capable of degrading casein. Presumably these enzymes make peptides and amino acids available near the cell surface. Law et al. (1976) showed that strains of Group $N$ streptococci commonly used as cheese starters utilized peptide mixtures as amino acid sources. Although some strains of Streptococcus cremoris utilized dipeptides as readily as the equivalent free amino acids, others only grew with free amino acids (Law, 1977). Streptococcus lactis also utilized dipeptides, but uptake competition between peptides was not demonstrable by growth response experiments, and the ability of whole cells of $S$. lactis (but not $S$. cremoris) to hydrolyse dipeptides suggested that this organism may not be entirely dependent on the transport of intact peptides. The present study was undertaken to determine the characteristics of di- and oligopeptide utilization in Group $\mathrm{N}$ streptococci and to determine the relative importance of peptide transport and extracellular hydrolysis in peptide utilization by $S$. lactis.

\section{METHODS}

Bacteria and growth. Strains of $S$. cremoris and $S$. lactis were obtained from the National Collection of Dairy Organisms (NCDO), Shinfield, Reading. The cultures were maintained by daily transfer in litmus milk and incubated at $22^{\circ} \mathrm{C}$. A variant of $S$. cremoris NCDO 924 which grew and produced acid more slowly in milk than the parent strain was supplied by Dr E. I. Garvie, National Institute for Research in Dairying, Shinfield, Reading. The 'slow' variant grew normally in a defined medium (Ford, 1962) containing a complete mixture of amino acids. Experiments in non-milk media were preceded by two transfers in the new medium. Growth experiments to determine peptide utilization were carried out as described previously (Law, 1977).

Materials. Amino acids were purchased from BDH. Unless otherwise stated, peptides and peptide deriva- 
tives were purchases from Sigma. tert-Butyl esters of L-leucyl-L-leucine and L isoleucyl-L-threonyl-Lglutamic acid were generous gifts from Dr J. S. Morley, ICI Ltd, Alderley Park, Cheshire. [U-14C]Leucine and glycyl[U- $\left.{ }^{14} \mathrm{C}\right]$ leucine were purchased from The Radiochemical Centre, Amersham.

Peptide and amino acid transport. Transport of $\left[\mathrm{U}-{ }^{14} \mathrm{C}\right]$ leucine or glycyl[U- $\left.{ }^{14} \mathrm{C}\right]$ leucine was measured by a method based on that of Britten \& McClure (1962). The streptococci were grown on Yeast Glucose Broth (Naylor \& Sharpe, 1958) to mid-exponential phase, harvested by centrifugation at $2000 \mathrm{~g}$ for $20 \mathrm{~min}$ and resuspended in the glucose-free, nitrogen-free basal medium of Ford (1962) at pH 6.5. The $A_{580}$ (Lumetron Colorimeter, model 401 ; Photovolt Corp., New York, U.S.A.) was adjusted to give suspensions containing the equivalent of $0.75 \mathrm{mg}$ dry wt organisms $\mathrm{ml}^{-1}$ (calculated from appropriate calibration curves for each strain). The cells were incubated at $30^{\circ} \mathrm{C}$ for $15 \mathrm{~min}$ before adding glucose $(0 \cdot 1 \% \mathrm{w} / \mathrm{v}$, final concentration). After a further $15 \mathrm{~min}$ glycyl[U- $\left.{ }^{14} \mathrm{C}\right]$ leucine $\left(6 \mu \mathrm{Ci} \mathrm{mmol}{ }^{-1}\right)$ or $\left[\mathrm{U}^{-14} \mathrm{C}\right]$ leucine $(3 \mu \mathrm{Ci} \mathrm{mmol}-1)$ was added $(0.5 \mathrm{~mm}$, unless otherwise stated) and $1 \mathrm{ml}$ of suspension was sampled immediately and at specified time intervals. Control incubations lacked bacteria. In some experiments potential competitors for dipeptide transport were added $(2.0 \mathrm{~mm}$ final concentration) at the same time as the radioactive compounds. Samples were collected on Millipore filters $(0.45 \mu \mathrm{m}$ pore size) and washed with $5 \mathrm{ml}$ glucose-free, nitrogen-free basal medium at $30^{\circ} \mathrm{C}$. After drying, the filters were immersed in $10 \mathrm{ml}$ butyl-PBD/POPOP in toluene [butylPBD: 2-(4'-tert-butylphenyl)-5-(4"-biphenylyl)-1,3,4-oxadiazole; POPOP: 1,4-di-2-(5-phenyloxazolyl)benzene] and radioactivity was measured in a liquid scintillation spectrometer (Packard B2450, Downers Grove, Illinois, U.S.A.).

Peptidase assay. The hydrolysis of peptides and their derivatives was detected as described by Law, Sharpe \& Reiter (1974).

\section{RESULTS}

Transport of glycyl $\left[U-{ }^{14} C\right]$ leucine and $\left[U-{ }^{14} C\right]$ leucine by $S$. cremoris and $S$. lactis

Three strains of $S$. cremoris and one of $S$. lactis transported approximately the same amount of leucine in 20 min (Fig. 1). Streptococcus cremoris NCDO 2016 did not transport glycylleucine at all and S. cremoris NCDO 1986 transported only $10 \%$ as much glycylleucine as leucine. Streptococcus cremoris NCDO 1196 and S. lactis NCDo 2017 transported, respectively, twice as much and $40 \%$ as much glycylleucine as leucine. There was no transport of leucine or glycylleucine in the absence of glucose or when 2,4-dinitrophenol (1.0 to $5.0 \mathrm{~mm}$ ) was added to the suspensions. Uptake after 2 min incubation increased with increasing concentrations of extracellular leucine or glycylleucine and appeared to be saturated by approximately $0.3 \mathrm{~mm}$-amino acid or $0.8 \mathrm{~mm}$-peptide in both organisms.

\section{Specificity determinants for dipeptide transport}

The affinity of amino acids, peptides and peptide derivatives for the dipeptide transport system was investigated by determining their ability to inhibit glycyl[U- $\left.{ }^{14} \mathrm{C}\right]$ leucine uptake. None of the amino acids tested inhibited glycyl[U- $\left.{ }^{14} \mathrm{C}\right]$ leucine uptake, suggesting transport of the intact dipeptide. Only unsubstituted dipeptides competed with glycylleucine for uptake (Table 1). Inhibition of glycylleucine uptake by alanylglycine and glycylhistidine was relatively weak though glycylhistidine was tested only in $S$. cremoris. Dipeptide competition was generally weaker in $S$. lactis than in $S$. cremoris. The transport system appeared to be specific for dipeptides since neither amino acids nor tripeptides competed with glycylleucine for uptake. Substitution of the N-terminal amino acid, as in Cbz-leucylglycine (Cbz: $\mathrm{N}$-benzyloxycarbonyl), prevented uptake competition in both organisms; substitution of the C-terminal residue, as in leucylleucine tert-butyl ester, also prevented competition for uptake in $S$. cremoris and greatly decreased it in S. lactis. Dipeptides containing $\beta$-amino acids or D-amino acid residues did not compete with glycylleucine for uptake.

\section{Growth of S. cremoris and S. lactis in media containing substituted dipeptides}

Streptococcus cremoris NCDO 1196 did not grow in defined peptide media in which free leucine was replaced by $3 \mathrm{~mm}$-Cbz-leucylglycine or leucylleucine tert-butyl ester, although this organism has previously been shown to utilize the corresponding unsubstituted dipeptides 


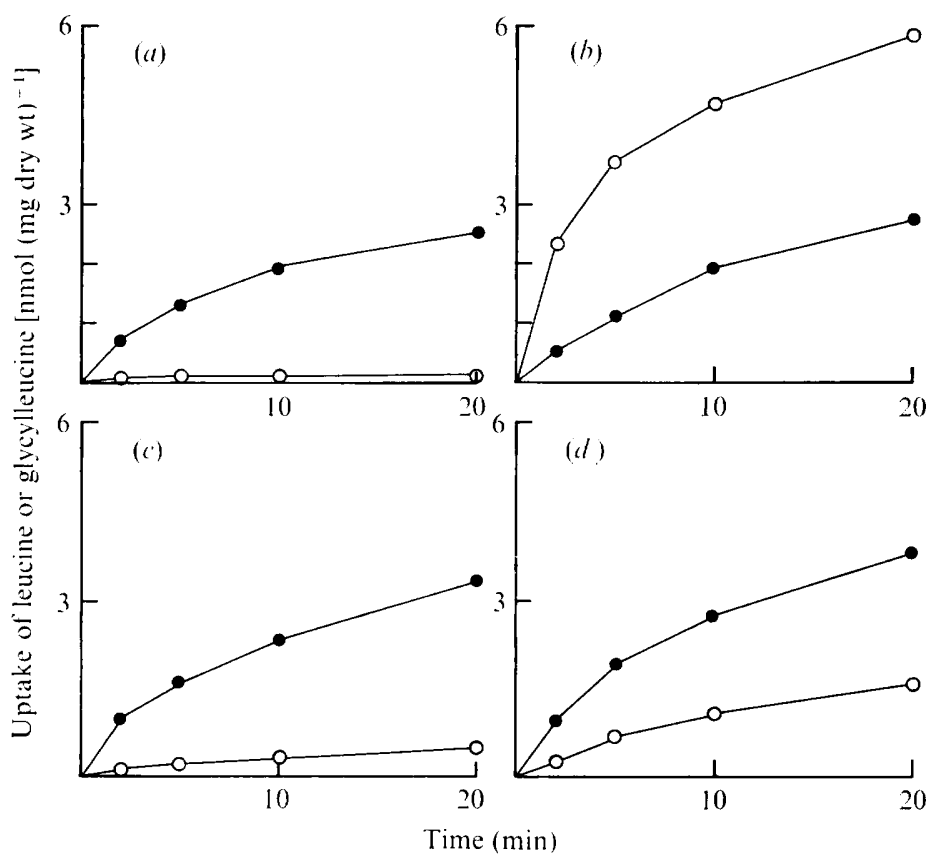

Fig. 1. Uptake of $\left[\mathrm{U}-{ }^{14} \mathrm{C}\right]$ leucine and glycyl[U-14 C]leucine by Group N streptococci : $(a)$ S. cremoris NCDO 2016; (b) S. cremoris NCDo 1196; (c) S. cremoris NCDo 1986; (d) S. lactis NCDO 2017. Cultures were grown to mid-exponential phase, washed, suspended at a density equivalent to $0.75 \mathrm{mg}$ dry wt organisms $\mathrm{ml}^{-1}$ and incubated at $30^{\circ} \mathrm{C}$ for $15 \mathrm{~min}$ without glucose, followed by $15 \mathrm{~min}$ with glucose $(0.1 \%, \mathrm{w} / \mathrm{v})$ before adding the amino acid $(\odot)$ or peptide $(O)$ at $0.5 \mathrm{~mm}$. At intervals, $1 \mathrm{ml}$ samples were taken, collected on Millipore filters, washed, dried and membrane-bound radioactivity was estimated. Amounts of amino acid or peptide taken up were calculated from radioactive counts corrected for background determined with filters from control incubations without organisms.

(Law, 1977). Streptococcus lactis NCDO 2017 did not grow with Cbz-leucylglycine but grew to $A_{580}=0.12$ with leucylleucine tert-butyl ester, compared with $A_{580}=0.36$ with an equimolar amount of unsubstituted leucylleucine. Law (1977) showed that intact S. lactis, unlike intact $S$. cremoris, hydrolysed dipeptides. Similar experiments in this study showed that $S$. lactis hydrolysed the butyl ester at about $25 \%$ of the rate of leucylleucine hydrolysis. Neither organism hydrolysed Cbz-leucylleucine.

\section{Tri- and tetrapeptide utilization by S. cremoris and S. lactis}

The characteristics of oligopeptide utilization were studied using growth response experiments (Law, 1977) in which tri- and tetrapeptides were used as sources of essential amino acids or as competitors for tripeptide utilization. Both S. cremoris NCDO 1196 and S. lactis NCDO 2017 grew as well when leucine or valine were supplied in tripeptides as they did with the free amino acids (Table 2) but growth with the tetrapeptide asparaginylisoleucylthreonylglutamic acid as a source of isoleucine or glutamic acid was only about $20 \%$ that of growth with the free amino acids. Isoleucylthreonylglutamic acid tert-butyl ester was utilized as a source of isoleucine but Cbz-glycylhistidylleucine was a poor source of leucine or histidine (Table 2). Di- and tripeptides containing L- but not D-amino acid residues competed for alanylleucylglycine utilization in S. cremoris NCDO 1196 growing on the latter peptide, but the resulting inhibition of growth (50 to $70 \%$ ) was not as strong as that observed previously (Law, 1977) with dipeptides competing for dipeptide utilization.

Streptococcus cremoris NCDO 2016, which did not utilize dipeptides (Law, 1977) or take up glycyl[U-14 $\mathrm{C}]$ leucine, did not utilize tripeptides as a source of essential amino acids in 
Table 1. Uptake of glycyl[ $\left.U-{ }^{14} C\right]$ leucine by Streptococcus cremoris NCDo 1196 and S. lactis NCDO 2017 in the presence of amino acids, peptides and peptide derivatives

Uptake conditions were as described in Fig. 1 except that the uptake was measured for 10 min'from the time of simultaneous addition of glycylleucine $(0.5 \mathrm{~mm})$ and the potential competitor $(2.0 \mathrm{~mm})$. Results are expressed as a percentage of the uptake in the absence of the competitor.

Glycyl[U-14 $\left.{ }^{14}\right]$ leucine uptake

Potential competitor
Leu, Val, Gly, His*
Gly-Val
Leu-Gly
Leu-Leu
Ala-Leu
Ala-Gly
Leu-Phe
Gly-His
Cbz-Leu-Gly
Leu-Leu-OBu
Leu- $\beta$-Ala
$\beta-$ Ala-Leu
D-Leu-D-Leu
D-Leu-L-Leu
L-Leu-D-Leu
Ala-Leu-Gly
Ala-Gly-Gly
Gly-Val-Ile

$\begin{array}{cc}\text { S. cremoris } & \text { S. lactis } \\ 100 & 100 \\ 4 & 53 \\ 6 & 34 \\ 6 & 33 \\ 8 & 31 \\ 53 & 67 \\ 15 & \text { NT } \\ 75 & \text { NT } \\ 100 & 94 \\ 100 & 78 \\ 96 & 98 \\ 100 & 98 \\ 100 & 100 \\ 100 & 96 \\ 100 & 94 \\ 100 & 96 \\ 100 & 100 \\ 100 & 91\end{array}$

NT, Not tested. Cbz, $N$-Benzyloxycarbonyl; $\mathrm{OBu}^{t}$, tert-butyl ester.

* Amino acids added separately.

Table 2. Growth of Streptococcus cremoris and $S$. lactis in media containing tri- and tetrapeptides as sources of essential amino acids

Growth was measured at $580 \mathrm{~nm}$ after $17 \mathrm{~h}$ incubation at $22^{\circ} \mathrm{C}$ in the chemically defined medium of Ford (1962). Essential amino acids were omitted singly from the medium and replaced by peptides (3.0 mM) containing the corresponding amino acid. Results represent the mean of two determinations (maximum variation $\pm 10 \%$ of mean).

\begin{tabular}{|c|c|c|c|c|c|}
\hline \multirow[b]{3}{*}{ Peptide } & \multirow{3}{*}{$\begin{array}{l}\text { Amino } \\
\text { acid } \\
\text { omilted }\end{array}$} & \multicolumn{4}{|c|}{$\%$ Growth response* } \\
\hline & & \multicolumn{2}{|c|}{ S. cremoris strains } & \multicolumn{2}{|c|}{ S. lactis strains } \\
\hline & & 1196 & 1986 & 2017 & 763 \\
\hline Ala-Leu-Gly & Leu & 110 & 75 & 87 & 91 \\
\hline Leu-Gly-Gly & Leu & 98 & 64 & 90 & 70 \\
\hline \multirow[t]{2}{*}{ Gly-Val-Ile } & Ile & 106 & 70 & 92 & 82 \\
\hline & Val & 100 & 70 & 86 & 76 \\
\hline Val-Gly-Gly & Val & 106 & 66 & 85 & 87 \\
\hline \multirow[t]{2}{*}{ Asn-Ile-Thr-Glu } & Ile & 26 & 19 & 20 & 16 \\
\hline & Glu & 20 & 15 & 15 & 15 \\
\hline Ile-Thr-Glu-OBu ${ }^{t}$ & Ile & 67 & 48 & 66 & 78 \\
\hline \multirow[t]{3}{*}{ Cbz-Gly-His-Leu } & Leu & 5 & 5 & 10 & 10 \\
\hline & His & 5 & 5 & 5 & 5 \\
\hline & Growt & h peptic & & & \\
\hline
\end{tabular}


tests identical to those described in Table 2. However, S. cremoris NCDO 1986, which grew very poorly on dipeptides (Law, 1977) and took up glycyl[U-14C]leucine only slowly, grew relatively well with tripeptides as a source of essential amino acids (Table 2).

\section{Peptide transport by a 'slow' variant of $S$. cremoris}

Streptococcus cremoris NCDO 924, and the variant which produced acid only slowly in milk, grew equally well with leucylglycine or alanylleucylglycine as a source of leucine in defined media. Both organisms also took up about $2 \cdot 3 \mathrm{nmol}\left[\mathrm{U}-{ }^{14} \mathrm{C}\right] l e u c i n e(\mathrm{mg} \text { dry wt })^{-1}$ or $4.9 \mathrm{nmol}$ glycyl[ $\left.\mathrm{U}^{14} \mathrm{C}\right]$ leucine $(\mathrm{mg} \text { dry wt})^{-1}$ in $20 \mathrm{~min}$ under the conditions described in Fig. 1.

\section{DISCUSSION}

Comparison of $\left[\mathrm{U}-{ }^{14} \mathrm{C}\right]$ leucine transport and glycyl[U- $\left.{ }^{14} \mathrm{C}\right]$ leucine transport in $S$. cremoris NCDO 2016 and 1986 shows that the previously reported failure of these strains to utilize dipeptides as amino acid sources is due to their inability to transport them rather than to any deficiency of intracellular dipeptidase activity, which is similar in dipeptide-utilizing and non-utilizing strains (Law, 1977). This also suggests that amino acid transport and dipeptide transport are distinct since one can be present without the other. The lack of competition for transport between amino acids and dipeptides confirms this distinction. Both dipeptide and amino acid transport exhibit saturation kinetics consistent with the existence of a carrier-mediated system. The lack of competition of tripeptides for the dipeptide system shows that it is exclusive to dipeptides, analogous to uptake in $E$. coli (Payne, 1968) and Pseudomonas putida (Cascieri \& Mallette, 1976).

Previous studies on the growth response of $S$. lactis in defined media (Law, 1977) showed that strains of this organism utilized dipeptides as amino acid sources. However since intact cells hydrolysed dipeptides, utilization did not necessarily involve peptide transport. The present results show that glycylleucine is taken up in competition with other dipeptides, but not with amino acids, indicating transport in the dipeptide form. However, dipeptide competition was invariably weaker than it was in $S$. cremoris, suggesting that extracellular hydrolysis of dipeptides allowed a proportion of the radioactivity to be transported as free leucine in $S$. lactis. Alternatively, glycylleucine may be a particularly good substrate of the transport system in $S$. lactis.

The competition for glycylleucine uptake by dipeptides containing a variety of amino acid residues indicates that there is a common transport system for all dipeptides, as in E. coli (Payne, 1975), although relative affinities differed sufficiently to suggest that other more specific systems may exist for the transport of dipeptides containing particular types of structurally-related amino acids, as proposed by Leach \& Snell (1960) for Lactobacillus casei. The inability of $\mathrm{N}$-terminal or $\mathrm{C}$-terminal substituted dipeptides, dipeptides containing $\beta$-alanine and dipeptides containing $\mathrm{D}$-amino acid residues to compete with glycylleucine uptake indicates that the structural requirements for dipeptide transport in $S$. cremoris and $S$. lactis are similar to those reported in E. coli (Payne, 1976) and P. putida (Cascieri \& Mallette, 1976), although the C-terminal substituted dipeptides may have some affinity for the system in S. lactis. However, the apparent competition between leucylleucine tert-butyl ester and glycyl[ $\left[{ }^{4} \mathrm{C}\right]$ leucine may have been due to competition between leucine and $\left[{ }^{14} \mathrm{C}\right]$ leucine liberated extracellularly from the dipeptides.

The growth of $S$. cremoris with tri- and tetrapeptides as amino acid sources and the competition for utilization indicates that this organism has an oligopeptide transport system in addition to the dipeptide system, although dipeptides appear to have an affinity for the tripeptide system. This may explain why $S$. cremoris NCDO 1986 grew on, and transported dipeptides only slowly, yet grew well with tripeptides as a source of leucine. Presumably this strain has no dipeptide system but an intact oligopeptide system on which dipeptides can be transported to a limited extent. Streptococcus cremoris NCDO 2016 appears to be 
deficient in both systems. The observation that glycylleucine uptake is similar in a slow acid-producing variant and in the parent strain of $S$. cremoris supports the conclusion (Exterkate, 1976) that defective proteolysis, rather than transport, is the primary reason for the poor growth of such variants in milk.

Utilization of tri- and dipeptides was similar in requiring an unsubstituted $\mathrm{N}$-terminal amino acid residue, but $\mathrm{C}$-terminal substituted tripeptides were utilized. D-Leucylglycylglycine could not be tested directly as an amino acid source since D-leucine itself would not be utilized, and glycine is not essential for growth. However, D-leucylglycylglycine did not compete with L-leucylglycylglycine for utilization so it is assumed that tripeptides containing D-amino acids are not transported by the oligopeptide system. The relatively poor growth of $S$. cremoris on a tetrapeptide, and the previous report from studies with peptide mixtures (Law et al., 1976), support the view that the size limit for utilization is approached at four residues and exceeded at seven. This is within the limits determined for $E$. coli (Payne, 1975).

The concerted effect of cell wall-bound proteinases, intracellular peptidases and the dipeptide, oligopeptide and amino acid transport systems presumably ensures that Group $\mathrm{N}$ streptococci growing in milk are supplied with the essential amino acids.

I thank Dr J.S. Morley for the gift of peptide derivatives, Miss A. Skolimowski and $\mathrm{Mr}$ A. J. Cliffe for technical assistance, and the radioactivity assay service of this Institute for counting radioactive samples and processing the results.

\section{REFERENCES}

Britten, R. J. \& MCClure, F. T. (1962). The amino acid pool in Escherichia coli. Bacteriological Reviews 26, 292-335.

Cascieri, T. \& Mallette, M. F. (1976). Peptide utilization by Pseudomonas putida and Pseudomonas maltophila. Journal of General Microbiology 92, 283-295.

ExTerkate, F. A. (1975). An introductory study of the proteolytic system of Streptococcus cremoris strain HP. Netherlands Milk and Dairy Journal 29, 303-318.

Exterkate, F. A. (1976). The proteolytic systern of a slow lactic acid-producing variant of Streptococcus cremoris HP. Netherlands Milk and Dairy Journal 30, 3-8.

ForD, J. E. (1962). A microbiological method for assaying the nutritional value of proteins. British Journal of Nutrition 16, 409-425.

LAw, B. A. (1977). Dipeptide utilization by starter streptococci. Journal of Dairy Research 44, 309317.

Law, B. A., Sharpe, M. E. \& Reiter, B. (1974). The release of intracellular dipeptidase from starter streptococci during Cheddar cheese ripening. Journal of Dairy Research 41, 137-146.

Law, B. A., Sezgin, E. \& Sharpe, M. E. (1976). The amino acid nutrition of some commercial cheese starters in relation to their growth in peptonesupplemented whey media. Journal of Dairy Research 43, 291-300.
Lawrence, R. C., Thomas, T. D. \& Terzaghi, B. E. (1976). Reviews in the progress of dairy science: cheese starters. Journal of Dairy Research 43, 141-193.

LeACH, F. R. \& SNell, E. E. (1960). The absorption of glycine and alanine and their peptides by Lactobacillus casei. Journal of Biological Chemistry 235, 3523-3531.

NAyLor, J. \& Sharpe, M. E. (1958). Lactobacilli in Cheddar cheese. I. The use of selective media for isolation and of serological typing for identification. Journal of Dairy Research 25, 92-103.

PAYNe, J. W. (1968). Oligopeptide transport in Escherichia coli. Specificity with respect to side chain and distinction from dipeptide transport. Journal of Biological Chemistry 243, 3395-3403.

PAYNe, J. W. (1975). Peptide transport in microorganisms. In Peptide Transport in Protein Nutrition, pp. 283-365. Edited by D. M. Matthews \& J. W. Payne. Amsterdam and New York: North Holland.

PAYNe, J. W. (1976). Peptides and micro-organisms. Advances in Microbial Physiology 13, 55-113.

Thomas, T. D., JARvis, B. D. W. \& Skipper, N. A. (1974). Localization of proteinases near the cell surface of Streptococcus lactis. Journal of Bacteriology 118, 329-333. 